\title{
Firn air depletion as a precursor of Antarctic ice-shelf collapse
}

\author{
Peter KUIPERS MUNNEKE, ${ }^{1}$ Stefan R.M. LIGTENBERG, ${ }^{1}$ \\ Michiel R. VAN DEN BROEKE, ${ }^{1}$ David G. VAUGHAN ${ }^{2}$ \\ ${ }^{1}$ Institute for Marine and Atmospheric Research, Utrecht University, Utrecht, The Netherlands \\ E-mail: p.kuipersmunneke@uu.nl \\ ${ }^{2}$ British Antarctic Survey, Natural Environment Research Council, Cambridge, UK
}

\begin{abstract}
Since the 1970s, the sudden, rapid collapse of $\sim 20 \%$ of ice shelves on the Antarctic Peninsula has led to large-scale thinning and acceleration of its tributary glaciers. The leading hypothesis for the collapse of most of these ice shelves is the process of hydrofracturing, whereby a water-filled crevasse is opened by the hydrostatic pressure acting at the crevasse tip. This process has been linked to observed atmospheric warming through the increased supply of meltwater. Importantly, the low-density firn layer near the ice-shelf surface, providing a porous medium in which meltwater can percolate and refreeze, has to be filled in with refrozen meltwater first, before hydrofracturing can occur at all. Here we build upon this notion of firn air depletion as a precursor of ice-shelf collapse, by using a firn model to show that pore space was depleted in the firn layer on former ice shelves, which enabled their collapse due to hydrofracturing. Two climate scenario runs with the same model indicate that during the 21st century most Antarctic Peninsula ice shelves, and some minor ice shelves elsewhere, are more likely to become susceptible to collapse following firn air depletion. If warming continues into the 22nd century, similar depletion will become widespread on ice shelves around East Antarctica. Our model further suggests that a projected increase in snowfall will protect the Ross and Filchner-Ronne Ice Shelves from hydrofracturing in the coming two centuries.
\end{abstract}

KEYWORDS: ice/atmosphere interactions, ice-shelf break-up, ice shelves, polar firn, surface melt

\section{INTRODUCTION}

The Antarctic ice sheet, containing enough ice to raise global sea level by $>58 \mathrm{~m}$ (Fretwell and others, 2013), includes large ice shelves. These floating extensions drain $>80 \%$ of its grounded ice into the oceans. Ice shelves modulate the rate at which grounded ice is released into the oceans: the buttressing effect of ice shelves lends stability to the grounded parts of the Antarctic ice sheet, limiting the discharge of grounded ice into the ocean (Dupont and Alley, 2005). The longevity of many ice shelves within the West Antarctic ice sheet (Pritchard and others, 2012), and possibly the longevity of other major ice shelves (Hellmer and others, 2012), is under threat from erosion from below by warming ocean water. Sub-shelf melting thus acts as a potentially strong preconditioning mechanism for ice-shelf collapse. As an additional mechanism, observed ice-shelf thinning and collapse within the Antarctic Peninsula in the past few decades (Cook and Vaughan, 2010) have been attributed to regional atmospheric warming (Vaughan and others, 2003; Van den Broeke and others, 2005) rather than oceanic processes (Nicholls and others, 2012; Pritchard and others, 2012). Of these ice-shelf collapses, those of the Larsen $A$ (1995) and B (2002) ice shelves on the Antarctic Peninsula are best documented (Rott and others, 1996; Vaughan and Doake, 1996; Scambos and others, 2004). In both cases, tributary glaciers accelerated significantly after ice-shelf loss (De Angelis and Skvarca, 2003; Rignot and others, 2004; Rott and others, 2011) and have continued to lose mass since (Berthier and others, 2012), contributing to the observed acceleration of mass loss in the Antarctic Peninsula (Shepherd and others, 2012).

Many of the collapse events follow a distinct pattern: prior to the ice-shelf collapse, meltwater ponds on the surface, forming numerous large lakes on the ice-shelf surface (Scambos and others, 2000). After the emergence of these ponds, the ice shelf experiences a rapid break-up consisting of near-simultaneous rifting parallel to the ice-shelf front (perpendicular to the ice flow), shattering the ice shelf in numerous elongated icebergs (Scambos and others, 2009). The process of hydrofracturing is the leading hypothesis for this type of ice-shelf collapse, whereby meltwater collects in surface crevasses, exerting sufficient pressure at the propagating crack tip for the crevasse to penetrate through the entire ice-shelf thickness. Recently, the sudden drainage of melt ponds has been hypothesized to promote ice-shelf instability by inducing strong tensile flexure stresses in the ice shelf (MacAyeal and Sergienko, 2013).

\section{THE ROLE OF FIRN IN ICE-SHELF COLLAPSE}

The collapse of the Antarctic Peninsula ice shelves follows a multi-decade period of strong atmospheric warming in that area (Vaughan and others, 2003; Zazulie and others, 2010) unseen in the past millennium (Abram and others, 2013). As heuristic relations between ice-shelf collapse and atmospheric warming, both the $-9^{\circ} \mathrm{C}$ annual isotherm (Morris and Vaughan, 2003) and the limit of 200 positive degree-days per year (Fyke and others, 2010) have been suggested to coincide with the limit of present-day ice-shelf viability. However, no physical framework for these relations has yet been provided. Here we propose that the actual collapse events are preceded by decadal-scale processes in the firn layer overlying the ice shelves. Firn is the transitional product as snow containing loosely packed crystals metamorphoses into ice from which air has been, in part, 


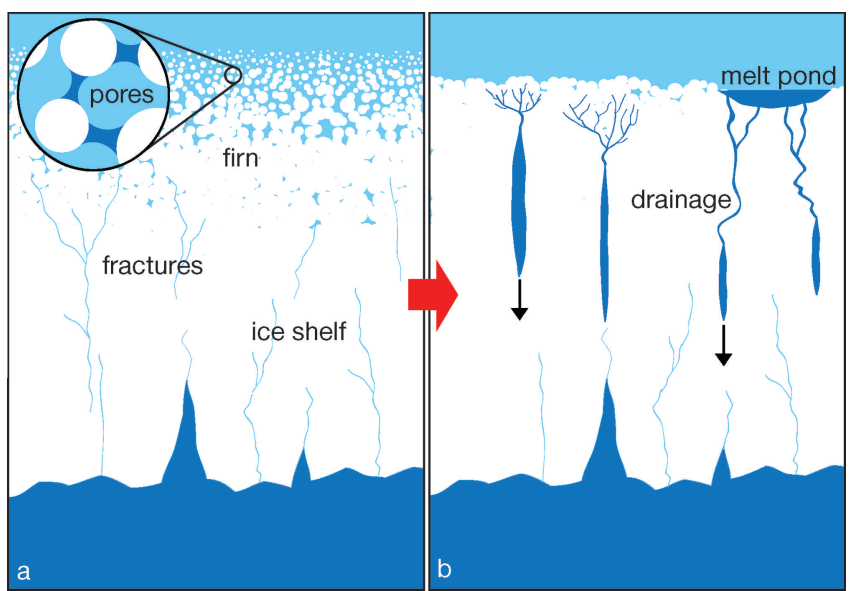

Fig. 1. Conceptual illustration of firn air depletion and its consequences for ice-shelf hydrology and stability. (a) An ice shelf covered by a firn layer containing sufficient air. The inset shows meltwater being stored in the pore space of the firn. (b) An ice shelf with a depleted firn layer. Due to the absence of pore space, meltwater forms ponds that drain into fractures. Alternatively, water is routed to the fractures efficiently as shown in the leftmost fractures.

expelled and, in part, absorbed into the crystal lattice. Firn consists of an ice matrix with interstitial air in an irregular and interconnected pore space. In an ice shelf containing sufficient firn air, surface meltwater percolates into the firn, and refreezes in its pore space (Fig. 1a). The firn acts as an absorbing buffer between surface meltwater and crevasses. As long as the volumes of pore space created by fresh snowfall and consumed by refreezing meltwater are similar, the buffer can continue to hold water away from major englacial fractures and faults in the ice shelf. No hydrofracturing will occur as a result, and the ice shelf will not be substantially weakened by the atmospheric forcing. However, when, over successive years, more pore space is lost by melt and densification than is gained by precipitation, the ice shelf is gradually depleted of air (Fig. 1b): surface meltwater no longer refreezes in the firn; instead, it sinks into and moves through the ice shelf, and into crevasses. Wherever the drainage capacity is insufficient, the firn is flooded, as observed on floating icebergs (Scambos and others, 2008), or collects into local surface depressions to form melt ponds (Scambos and others, 2000). Ponded meltwater can be routed in crevasses through surface streams or englacial channels, possibly created by tensile stresses released during lake drainage events (MacAyeal and Sergienko, 2013).

Both ponding and filling of crevasses should thus be considered the final stage of a preconditioning phase for iceshelf collapse. Importantly, both the meltwater ponding and the subsequent hydrofracturing emanate from the depletion of air in the firn pack. Depleted firn therefore emerges as a good indicator of ice-shelf instability with respect to atmospheric processes. This notion has been explored observationally using remotely sensed firn characteristics to assess ice-shelf stability (Scambos and others, 2003). Here we employ a model in which the evolution of the past and future firn layer over Antarctic ice shelves is simulated. Our aim is to elucidate the role that the firn layer has played in preconditioning recent ice-shelf collapse, and to assess its potential future role.

\section{A MODEL OF THE ANTARCTIC FIRN LAYER}

In the firn layer, freshly fallen snow metamorphoses into ice through a combination of firn densification (or compaction) and an annual cycle of melt, percolation and refreezing. The evolution of the firn is simulated here using a timedependent, one-dimensional firn-densification model that includes thermodynamics, dry firn compaction and snowpack hydrology including melt, percolation and refreezing. The model is forced with temperature, accumulation and melt at its upper boundary (see below), and calculates the resulting vertical density profiles, and surface elevation changes due to firn processes. The firn model is extensively documented by Ligtenberg and others (2011): it uses a modified version of the dry-firn densification equations by Arthern and others (2010) which has been validated against 38 firn cores around Antarctica. In these equations, the dryfirn densification rate depends on the mean accumulation rate. To allow for variation of the densification rate in time, the mean accumulation rate in the equations by Arthern and others (2010) is calculated as a running mean over the 40 years preceding each time-step.

For the firn hydrology, a so-called tipping-bucket method is employed: each firn layer has a maximum capillary water storage that decreases with increasing density (Coléou and others, 1999). If percolating surface meltwater encounters a saturated firn layer, it continues to move downward until it finds an unsaturated layer in which it can be stored as capillary water. This tipping-bucket approach performs well against other models of firn hydrology (Wever and others, 2013).

\section{Firn-model forcing 1980-2199}

The firn model is forced with daily mean surface temperature at the snow surface, and precipitation and melt fluxes from the regional atmospheric climate model RACMO2, adapted for simulating ice-sheet climate (Ettema and others, 2009; Kuipers Munneke and others, 2011a; Lenaerts and others, 2012). RACMO2 was run on a domain comprising the Antarctic continent and its surrounding oceans, at $55 \mathrm{~km}$ horizontal resolution. Because RACMO2 is a limited-area model, it needs to be forced with climate fields from a parent general circulation model (GCM). In this study, we employ HadCM3 as the parent GCM, and we refer to this configuration as R-H3. HadCM3 is among the bestperforming CMIP3 models over Antarctica (Connolley and Bracegirdle, 2007). We simulate the evolution of future climate under the emission scenarios A1B ('business as usual', rapid economic growth with balanced use of fossil and renewable fuels) and E1 ('aggressive emission mitigation', aiming at global warming stabilization below $2^{\circ} \mathrm{C}$ ). These scenarios represent two different possible future climate pathways, and the reliability of future firn evolution will depend on the ability of $\mathrm{R}-\mathrm{H} 3$ to simulate future climate. The future firn projections in this study serve as an exploration of future ice-shelf stability.

Before we can use the $\mathrm{R}-\mathrm{H} 3$ climate fields for our firn model, we have to evaluate the performance of $\mathrm{R}-\mathrm{H} 3$ for the climate reference period 1980-99. We do so by comparing $\mathrm{R}-\mathrm{H} 3$ to a run in which RACMO2 was forced with European Centre for Medium-Range Weather Forecasts ERA40 reanalysis data (henceforth R-ERA), a climate model reanalysis nudged towards surface and satellite observations. R-ERA reconstructs the true recent Antarctic climate as accurately as possible, whereas $\mathrm{R}-\mathrm{H} 3$ merely represents a possible 

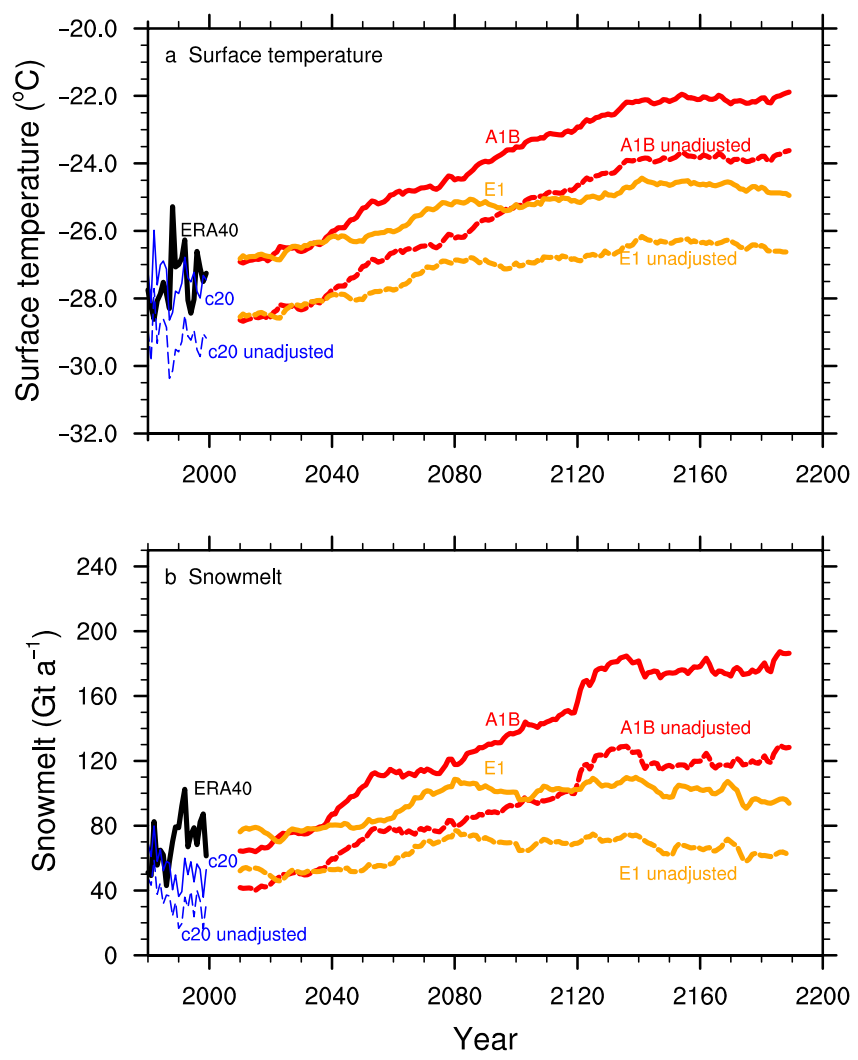

Fig. 2. (a) Mean surface temperature and (b) mean annual cumulative snowmelt volume over ice shelves only. Annual means for R-H3 (1980-99) are shown in dashed blue (original) and solid blue (adjusted based on R-ERA); annual means from ERA40 in solid black; and 20 year running mean surface temperature for E1 in orange and for A1B in red (unadjusted: dashed; adjusted based on R-ERA: solid).

climate realization occurring under present-day greenhousegas, volcanic, solar and aerosol forcings. Therefore, R-ERA is the better approximation of real climate during the reference period 1980-99. For this reference period, R-H3 simulates a climate that is both too dry (by $14 \%$ when aggregated over the continent) and too cold (by $1.5^{\circ} \mathrm{C}$ ) compared to R-ERA (Ligtenberg and others, 2013). The R-H3 output is adjusted to match the R-ERA output, both for the reference period 1980-99 and the subsequent climate projections for 20002199. For skin temperature, a spatially distributed temperature correction for each month is applied, based on the mean monthly difference between R-ERA and R-H3. Both the original and adjusted surface temperatures are shown in Figure 2. For accumulation (snowfall minus evaporation), R$\mathrm{H} 3$ is multiplied by a spatially and temporally uniform factor of 1.16 so that the continent-wide snowfall amount of R-H3 matches that of R-ERA (Ligtenberg and others, 2013). Finally, for the adjustment of R-H3 snowmelt, we apply a procedure in which we add a certain amount of snowmelt depending on the magnitude of the skin temperature adjustment. We fit three cubic splines to modelled annual R-ERA melt and annual R-ERA skin temperature (Fig. 3). Below an annual skin temperature of $245 \mathrm{~K}$, we assume no melt. Based on the original and adjusted skin temperature, an original and adjusted idealized melt flux are computed using the fit in Figure 3. The difference between these two is added to the modelled melt flux. As a result, R-H3 Antarctic annual snowmelt over the ice shelves increases from $34 \mathrm{Gta}^{-1}$ to

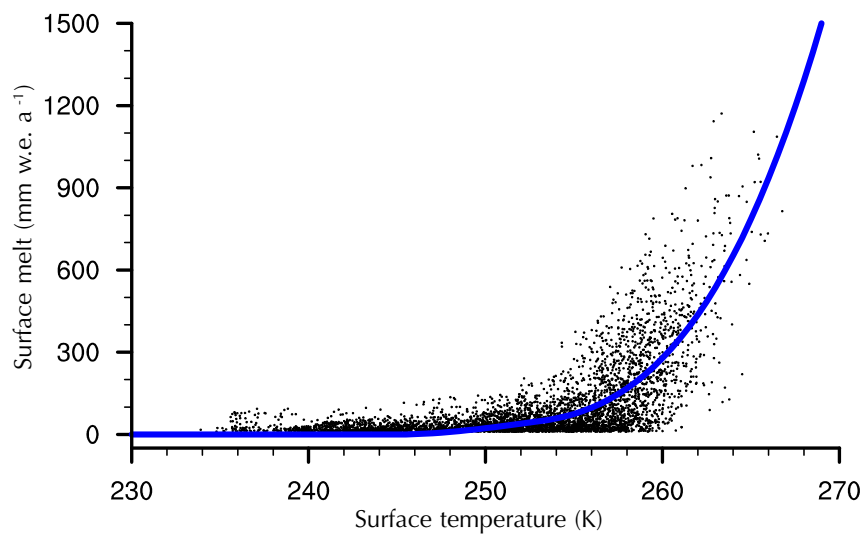

Fig. 3. Annual means of R-ERA modelled surface temperature versus annual means of R-ERA melt for each location and each year between 1980 and 2000. The blue line shows a fit to the data consisting of three cubic splines.

$54 \mathrm{Gta}^{-1}$, which is much closer to the R-ERA annual snowmelt of $70 \mathrm{Gta}^{-1}$ (Fig. 2).

Over the Larsen B and C ice shelves, the accuracy of R-H3 simulated snowfall and snowmelt fluxes is somewhat compromised: these shelves are located behind the high Antarctic Peninsula mountain range and oriented perpendicular to the dominating zonal flow, the dynamics of which are not sufficiently captured on a $55 \mathrm{~km}$ horizontal resolution model grid. To evaluate and adjust R-H3 snowfall and melt fluxes for this area, we used data from the automatic weather station AWS14 $\left(67^{\circ} 00.8^{\prime} \mathrm{S} 61^{\circ} 28.8^{\prime} \mathrm{W} ; 40\right.$ m a.s.l.) which has been operating continuously on the northern Larsen $C$ ice shelf since January 2009 (Kuipers Munneke and others, 2012). The annual melt flux is estimated from a calculation of the entire surface energy budget (Fig. 4). The resulting annual mean melt energy flux of $2.8 \mathrm{~W} \mathrm{~m}^{-2}$ corresponds to an observed melt amount of $260 \mathrm{~mm}$ w.e. $\mathrm{a}^{-1}$. AWS14 is also equipped with a sonic height ranger, which measures the distance between the fixed sensor and the snow surface. Over a 2 year period, it has observed a net surface height increase of $1.85 \mathrm{~m}$, corresponding to $324 \mathrm{~mm}$ w.e. $\mathrm{a}^{-1}$ assuming a density of $350 \mathrm{~kg} \mathrm{~m}^{-3}$ (Fig. 4). Neglecting other surface processes, this implies that annual mean snowfall is $584 \mathrm{~mm}$ w.e. $\mathrm{a}^{-1}$ for this period. R-H3 underestimates snowfall, at $344 \mathrm{~mm}$ w.e. $\mathrm{a}^{-1}$. The lack of fresh snowfall (which increases albedo) leads to an overestimation of melt by

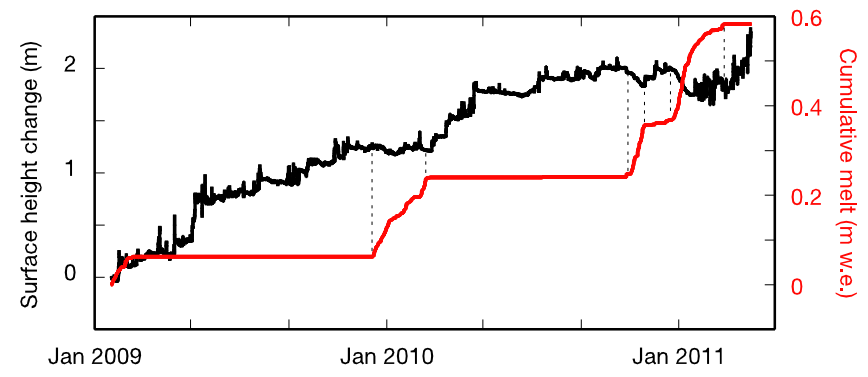

Fig. 4. Surface height change and cumulative melt at AWS14, northern Larsen C ice shelf $\left(67^{\circ} 00.8^{\prime} \mathrm{S} 61^{\circ} 28.8^{\prime} \mathrm{W} ; 40 \mathrm{~m}\right.$ a.s.I.), between January 2009 and April 2011. Surface height change in black with scale on the left; cumulative melt in red with scale on the right. The vertical dashed lines help to indicate the coincidence of surface lowering and melt occurrence. 

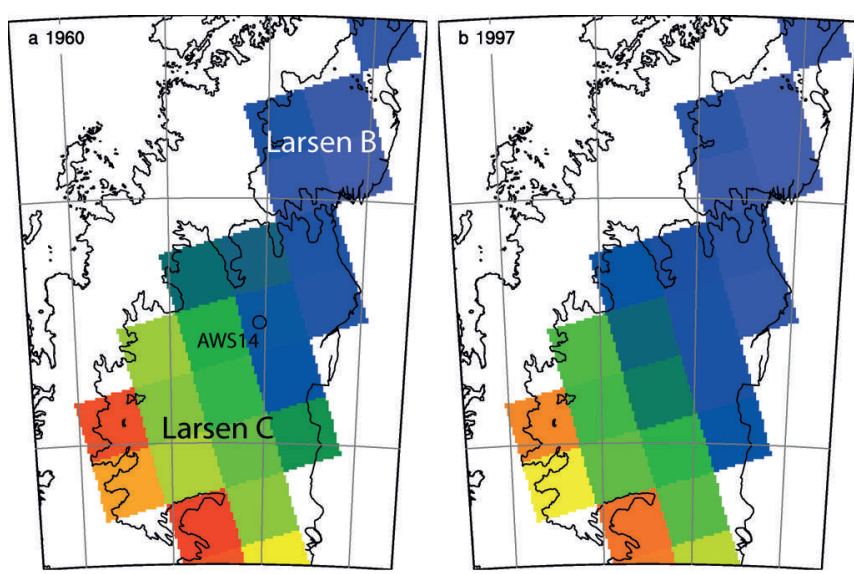

Firn air thickness (m)

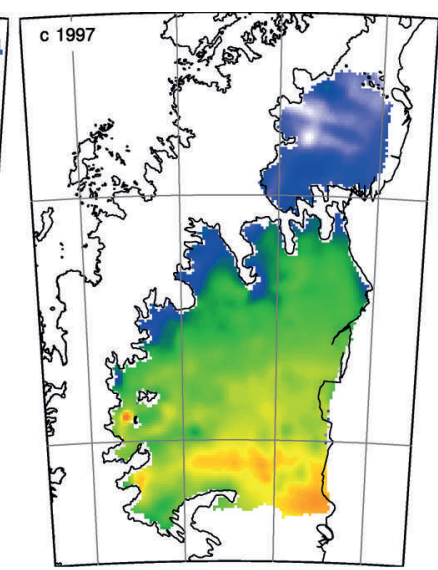

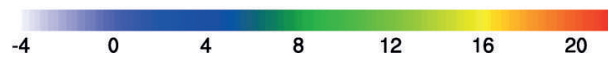

Fig. 5. Firn air thickness over the Larsen B and C ice shelves. (a) Modelled firn air thickness in January 1960, with black circle showing the location of AWS14 used to calibrate the firn model input; (b) modelled firn air thickness in January 1997; and (c) observed firn air thickness in January 1997 (data from Holland and others, 2011). Locations with negative values of firn air thickness in (c) are the result of the inversion method in Holland and others (2011) which assumes that the firn layer is completely dry. The unrealistic negative values indicate that this assumption does not hold, so there must be liquid water in the firn at these locations.

$\sim 20 \%$ (309 mm w.e. $\mathrm{a}^{-1}$ modelled vs $260 \mathrm{~mm}$ w.e. $\mathrm{a}^{-1}$ observed). We therefore adjusted snowfall in this area by a factor 1.69 , and reduced melt by a factor 0.83 . No other Antarctic ice shelves have this complex topography, so we did not adjust the firn model input over other ice shelves.

Under the A1B (E1) scenario, Antarctic snowfall increases by $17 \%(7 \%)$ by the year 2100 compared to the present day. Temperature increases by $3.0 \mathrm{~K}(2.0 \mathrm{~K})$, liquid precipitation increases by $158 \%$ (64\%) and snowmelt increases by $183 \%$ (134\%). After 2100, the E1 scenario stabilizes at the 2100 levels, with snowmelt slightly decreasing. Under the A1B scenario, all the above-mentioned mass-balance components continue to increase (Ligtenberg and others, 2013).

\section{Firn model forcing 1960-79}

To initialize a time integration, the firn model needs to be spun up. The total spin-up time required is given as the thickness of the entire firn pack divided by the mean annual precipitation, i.e. the time it takes to refresh the firn pack. In this way, all the model firn, from the top to the bottom of the firn pack, has density and temperature characteristics that are determined entirely by the climate preceding the start date of the time integration, and not by the choice of a model initialization. Because no climate data for such long periods before the present day are available, the model spinup is carried out by looping over a time series from a baseline period of two decades repeatedly until the desired spin-up period is complete. After the spin-up stage, the model integrates forward in time. Because the firn layer over ice shelves in the Antarctic Peninsula was likely not in equilibrium with the 1980-99 climate (for which R-H3 data are available), it would be inappropriate to use the period 1980-99 as a baseline period for the spin-up of the firn layer. Therefore, the starting year of the firn model integrations was moved backward from 1980 to 1960, spinning up the model by multiple cycles of the two decades 1960-79. For this period, firn model input was obtained from an observationbased surface temperature reconstruction (Monaghan and others, 2008), here referred to as the 'Monaghan reconstruction'. This procedure is detailed in the Appendix.

\section{Model strategy}

The resulting modelling strategy is now as follows: the model is spun up using the Monaghan reconstruction for the period 1960-79, repeated as many times as required to refresh the entire firn layer. An integration is then performed that starts in 1960, uses the Monaghan reconstruction up to 1979 once more, and then the HadCM3 data for the period 1980-2199. Thus, the firn pack is in equilibrium with the 1960-79 mean climate at the start of the simulation.

\section{RESULTS}

\section{Present-day firn layer}

As a single measure of the amount of pore space, we calculate the total air content of the firn layer, and express this as the thickness of the equivalent air column contained in the firn: we refer to this as the firn air thickness. The lowest values of firn air thickness $(0-5 \mathrm{~m})$ are found in warm areas with a high snowmelt/snowfall ratio (Larsen B, northern Larsen C, Wilkins, northern George VI; Figs 5, 6a and 7a). The 1960 and 1997 firn air thickness on the Larsen ice shelves (Fig. 5a and b) show a north-south gradient over the Larsen B and C ice shelves, which is confirmed by observed (Fig. 5c) firn air thickness from airborne radar altimetry in 1997 (Holland and others, 2011). This reflects the strong north-south temperature gradient in this part of the Antarctic Peninsula. The observed east-west gradient (Fig. 5c) is not captured well by the model, however. The observed low firn air thickness in the northwestern part of Larsen C is due to enhanced melt, likely caused by föhn winds that descend from the mountains west of it (Barrand and others, 2013; Trusel and others, 2013). RACMO2 has no capacity to resolve this effect, and instead produces a melt pattern that reflects a simplified altitudinal gradient from west to east. The same limitation of RACMO2 was noted in a comparison between satellite-derived and RACMO2-simulated melt duration (Barrand and others, 2013). The low model firn air thickness over the George VI Ice Shelf is confirmed by frequently observed ponding (Wager, 1972). With respect to the initial state of the firn in 1960, firn air thickness in 1997 is largely unchanged, except 


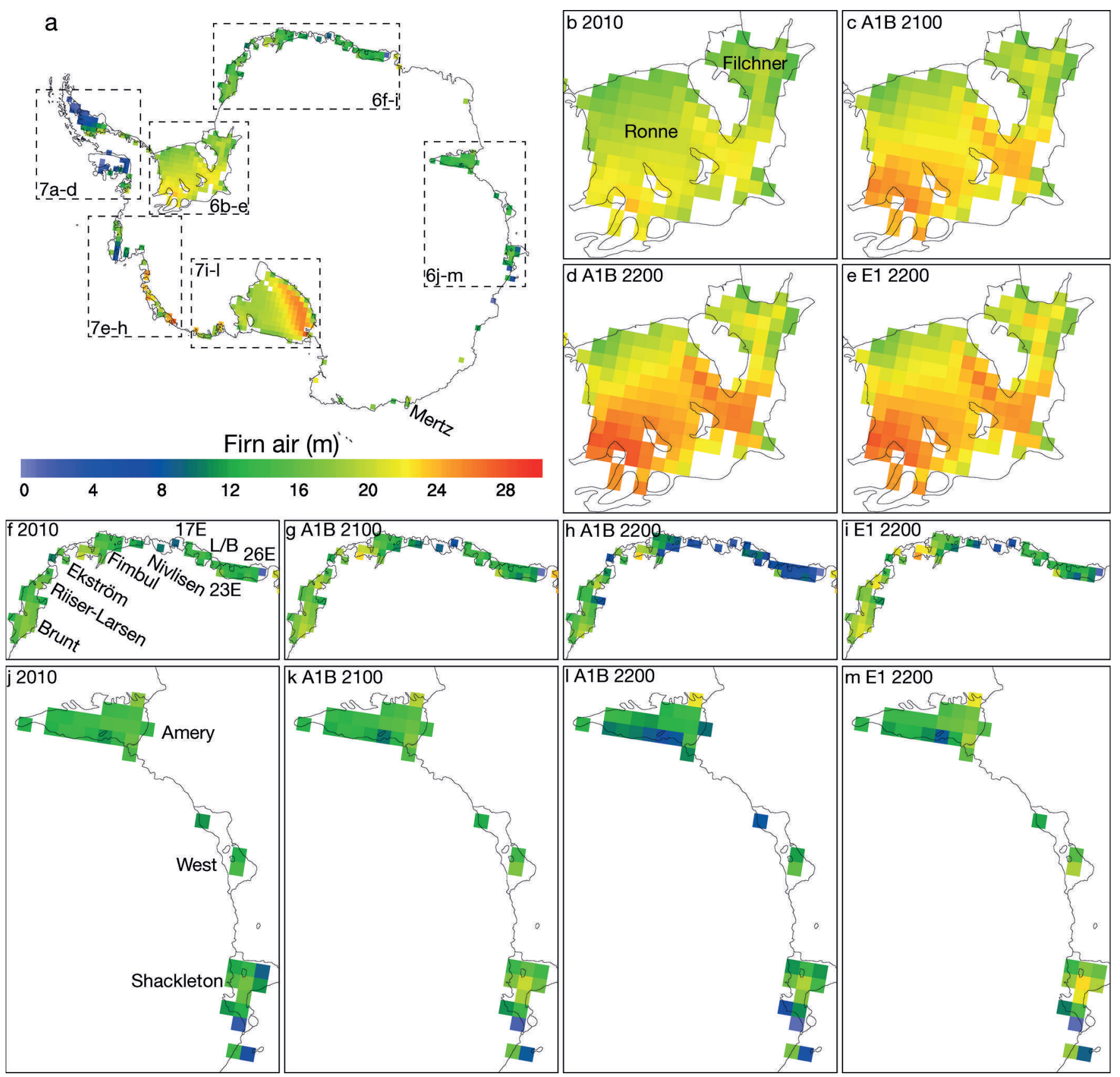

Fig. 6. Modelled firn air thickness on the Antarctic ice shelves. (a) Antarctica 2010. Dashed boxes indicate the subregions in the other panels of this figure and in Figure 7: $(\mathrm{b}-\mathrm{e})$ Filchner-Ronne Ice Shelf; $(\mathrm{f}-\mathrm{i})$ Dronning Maud Land ice shelves; and $(\mathrm{j}-\mathrm{m})$ Amery, West and Shackleton ice shelves.

on parts of the Larsen $\mathrm{C}$ and Abbot ice shelves, with firn air losses greater than $2.5 \mathrm{~m}$ in this period (Fig. 5).

Firn air thickness has been low on the collapsed Larsen A and $\mathrm{B}$ ice shelves since the beginning of the simulation in 1960. This means that these ice shelves have been susceptible to collapse for many decades prior to their actual break-up in 1995 and 2002, respectively. This implies that firn air depletion is a necessary preconditioning process, but not sufficient alone to cause hydrofracturing as soon as the firn air thickness has gone below a certain threshold. The occurrence of an actual collapse event will depend on other factors, such as the stress field in the ice shelf, and the occurrence of intense melt (Van den Broeke and others, 2005). Indeed, ponding of meltwater had already been observed since the 1980s (Skvarca and others, 1999;
Scambos and others, 2000), indicating that the firn air thickness had been low for many decades before collapse.

\section{Future firn-layer evolution}

Maps of future firn air thickness are shown in Figures 6 and 7, and time series of selected ice shelves in Figure 8 . In both the $\mathrm{A} 1 \mathrm{~B}$ and $\mathrm{E} 1$ emission scenarios, the firn air thickness of most Antarctic Peninsula ice shelves is reduced to $<2 \mathrm{~m}$ by the year 2100 (Fig. 7b), rendering them subject to extensive surface ponding, and possible hydrofracturing. The Larsen $\mathrm{C}$ ice shelf northern and central sections have lost a considerable amount of firn air. The mean thinning rate for 20002100 is 0.04 and $0.06 \mathrm{ma}^{-1}$ for northern and central Larsen $C$ respectively (thinning of other shelves shown in Fig. 8). Additionally, the firn air thickness over the western 


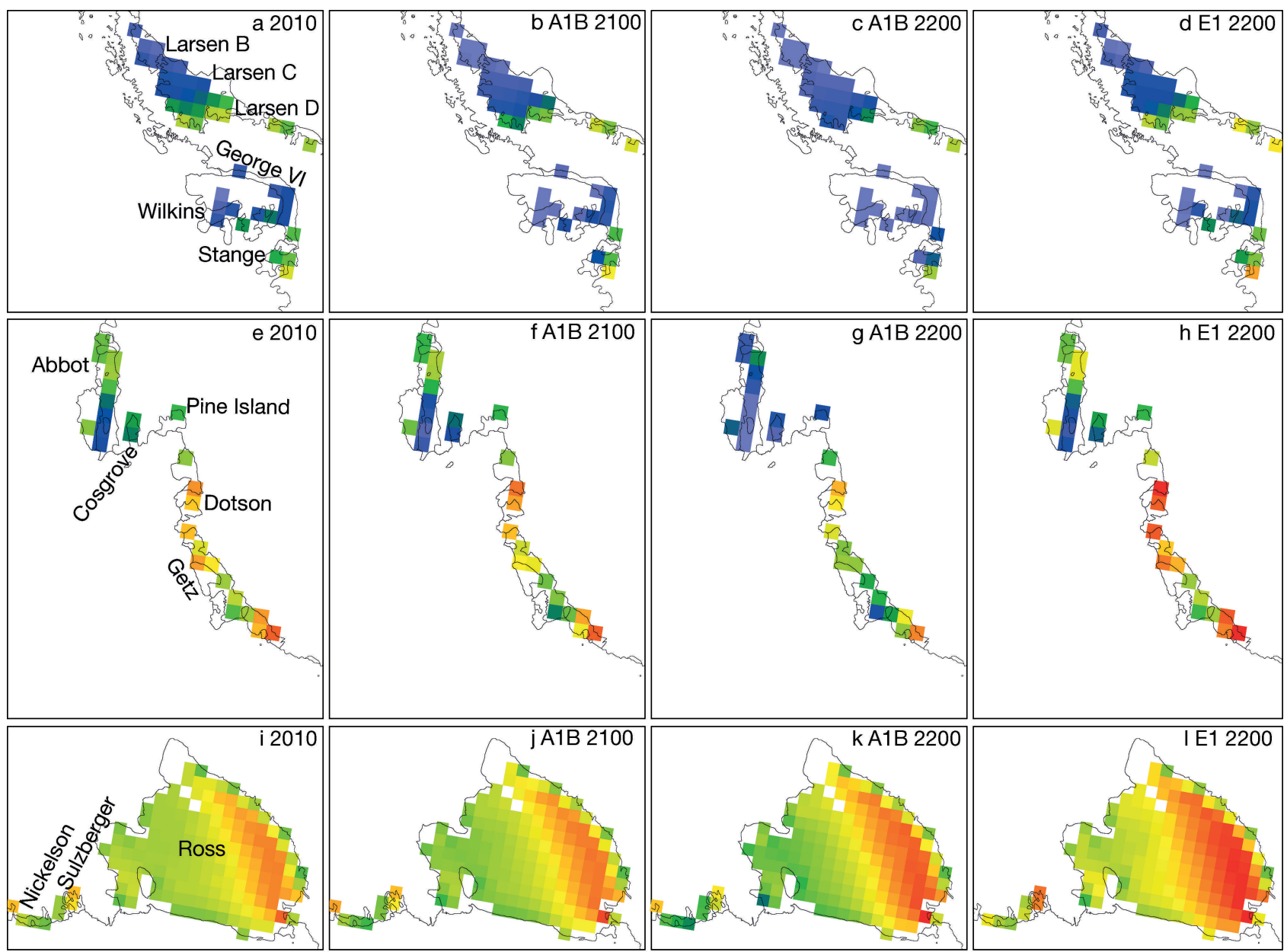

Firn air (m)

$\begin{array}{llllllll}0 & 4 & 8 & 12 & 16 & 20 & 24 & 28\end{array}$

Fig. 7. Modelled firn air thickness for (a-d) Antarctic Peninsula, (e-h) Bellingshausen and Amundsen Coast ice shelves and (i-l) Ross Ice Shelf. The 1960 ice-shelf outlines are used throughout the figure.

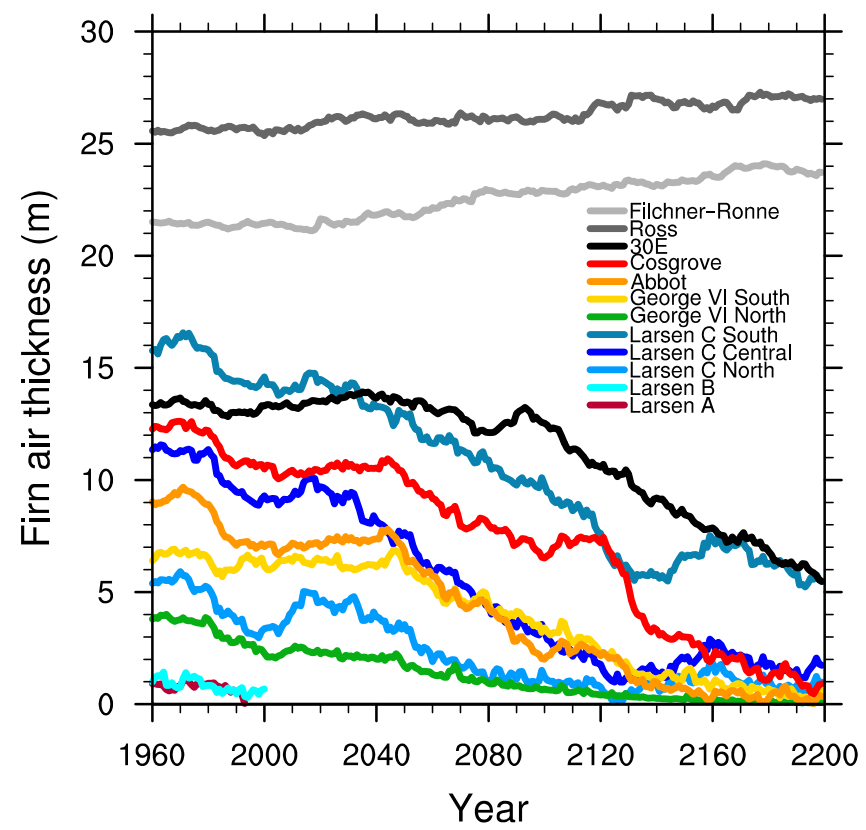

Fig. 8. Modelled firn air thickness for 12 ice-shelf locations as a function of time.
Abbot Ice Shelf on the coast of West Antarctica is low by 2100 in both scenarios, and depleted by 2140 (Figs $7 f$ and 8).

By 2200, there is a clear divergence between the A1B and E1 scenarios (Figs 6d, e, h, i, l, m and 7c, d, g, h, k, I). This divergence in firn air thickness represents the levelling-off of both air temperature and snowmelt in the E1 scenario. In this scenario, firn air thickness around Antarctica beyond 2100 remains similar to the projected E1 2100 values, as the climate stabilizes. In the A1B scenario, however, warming continues beyond 2100, subjecting the ice shelves to further increases in melt. In this scenario, the firn over the Stange (Fig. 7a-d), Abbot and Cosgrove ice shelves (Fig. 7e-h) becomes depleted of air. Moreover, the ice shelves fringing Dronning Maud Land (Fig. 6f-i) continue to lose air, and firn air thickness on the ice shelves east of Nivlisen (Fig. 6h) reaches values of $5 \mathrm{~m}$ or less. In our model study, aggressive mitigation thus limits the number of ice shelves under threat of collapse.

\section{DISCUSSION}

\section{Implication of accumulation changes}

To our knowledge, we are the first to attempt to quantify the influence of past and future climate change on the state of 

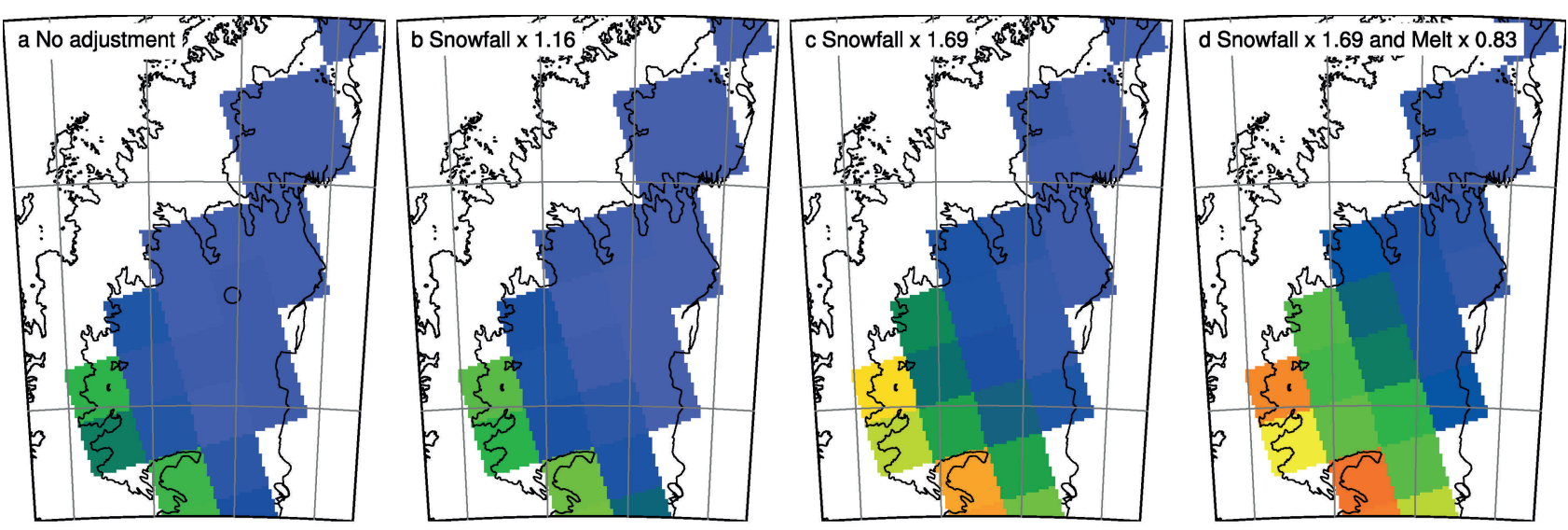

Firn air thickness $(\mathrm{m})$

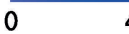

4

8

12

16

20

Fig. 9. Modelled firn air thickness $(\mathrm{m})$ in the eastern Antarctic Peninsula in 1997 for different adjustments of the forcing (snowfall and snowmelt). (a) No adjustments. (b) Multiplication of snowfall by a factor of 1.16. (c) Same as (b) but with a factor of 1.69 . (d) Same as (c) but with a reduction in snowmelt by a factor of 0.83 .

the Antarctic firn layer, whereby we point to potential hotspots for future ice-shelf collapse. Considering firn air thickness as a diagnostic metric for hydrofracturing susceptibility, not only changes in temperature have an effect on the available pore space, but also changes in solid precipitation: an increase in snowfall counteracts any decrease in firn air thickness due to increasing surface melt. This provides a more realistic assessment of susceptibility to hydrofracturing than a temperature-based threshold alone. As a striking example, the firn air thickness over the large Ross and Filchner-Ronne Ice Shelves gradually increases into the $21 \mathrm{st}$ and 22nd centuries (Fig. 6b-d), because the projected increase in snowfall adds more pore space to the firn than is removed by the projected increase in surface melt and temperature. This has the important implication that the Filchner-Ronne and Ross Ice Shelves, which are believed to buttress the West Antarctic ice sheet, are not susceptible to surface hydrofracturing over the next two centuries.

\section{Model uncertainties}

There are a number of uncertainties that impact the prediction of a potential ice-shelf collapse. These uncertainties can be roughly divided into two categories: (1) model uncertainty; and (2) the notion that the occurrence of an actual hydrofracturing event is not firmly connected to the passing of a certain threshold of firn air thickness. Below, we discuss a number of sources of uncertainty that are most important.

For dry firn compaction, the firn model was validated against 38 firn cores around Antarctica (Ligtenberg and others, 2011): the correlation $\left(r^{2}\right)$ between observed and modelled firn air thickness is 0.89 , and the root-mean-square value is $1.85 \mathrm{~m}$. This means that the timing of low firn air thickness over certain ice shelves has an uncertainty of a few decades. However, this analysis only pertains to the drycompaction part of the firn model. The model uncertainty with regard to meltwater processes is more difficult to quantify. However, at present almost all meltwater in Antarctica refreezes somewhere in the firn (Kuipers Munneke and others, 2011b). Since firn air thickness is a vertically integrated quantity, the details of this refreezing process are not critically important for the determination of firn air thickness: the uncertainty in the trends of firn air thickness is dominated by the uncertainty in the simulated melt fluxes rather than in the handling of meltwater in the firn model.

As detailed above, adjustments have been made to the R$\mathrm{H} 3$ forcing of the firn model in order to better represent the climate conditions on the eastern Antarctic Peninsula ice shelves. In Figure 9, we show the effect of various adjustments of snowfall and melt on the simulated firn air thickness over the Larsen B and C ice shelves (Fig. 9d is identical to Fig. 5b). It is clear that a custom adjustment of R$\mathrm{H} 3$ in this region is required to correctly simulate the observed firn air thickness in 1997 (Fig. 5c). Figure 9c and d also provide insight into the sensitivity of simulated firn air thickness to the prescribed melt flux. A reduction of the melt by $17 \%$ leads to markedly more firn air, with increases up to 4-5 $\mathrm{m}$ in some places. The most important improvement of our results would probably come from the availability of improved and spatially higher-resolution present-day and future climate data as input for the firn model.

\section{Firn depletion required but not sufficient}

Our results indicate that firn air thickness has been low over the Larsen A and B ice shelves for many decades prior to their collapse. It indicates that the actual collapse requires additional circumstances, such as a particularly strong melt event, a sufficiently weakened stress field of the ice shelf, or a combination of these.

We advocate that a depleted firn layer is a prime requirement for hydrofracturing, but the corollary that depleted firn will lead to hydrofracturing is not necessarily true. A key example is that of the George VI Ice Shelf: here low firn air thickness and extensive ponding of meltwater have been observed for several decades (Wager, 1972), but the ice shelf has survived to date, and has exhibited only marginal changes in extent over that period (Cook and Vaughan, 2010). The likely reason for the survival of the George VI Ice Shelf is an unusual stress field across most of the shelf, in which few crevasses are formed, and meltwater tends to remain ponded on the surface rather than opening cracks. Similar stress conditions probably exist elsewhere, particularly where ice flow is highly confined (e.g. the Amery Ice Shelf, East Antarctica), and this may preserve 
portions of ice shelves long after the firn air depletion criterion has been exceeded.

\section{CONCLUSION}

The recent observations of ice-shelf collapse within the Antarctic Peninsula following a strong multi-decadal atmospheric warming indicate that surface melting is linked to iceshelf collapse. We have developed a process-based model that can be used to assess past events and make predictions for the future. The model suggests that, under climate projections arising from two emission scenarios, over the next 200 years many more ice shelves will be threatened by similar preconditioning, which would in places lead to collapse. The rapid loss of such ice shelves would undoubtedly lead to acceleration of tributary glaciers and ice streams, as has been observed on the Antarctic Peninsula, and this will promote ice-loss and retreat of these glaciers. At the same time, a projected increase in snowfall would protect the large Ross and Filchner-Ronne Ice Shelves from hydrofracturing.

Ice-shelf thinning is already underway in some parts of Antarctica due to basal melting driven by ocean warming (Hellmer and others, 2012; Pritchard and others, 2012), and the ultimate fate of ice shelves responding to the complementary impacts of atmospheric and ocean drivers needs to be assessed before their potential longevity can be estimated.

\section{ACKNOWLEDGEMENTS}

We thank Andrew Monaghan (US National Center for Atmospheric Research (NCAR), Boulder, CO) for providing his Antarctic temperature reconstruction, and Paul Holland (British Antarctic Survey) for providing firn air thickness data over the Larsen ice shelves. Comments from two anonymous reviewers greatly helped to improve this paper. All the figures were plotted using the NCAR Command Language (version 6.1.3) (2013). This research was partly funded by NWO/ALW (Netherlands Organization of Scientific Research, Earth and Life Sciences section) grant 818.01.016, and partly supported by funding from the ice2sea programme of the European Union 7th Framework Programme, grant No. 226375. This is ice2sea contribution No. 123.

\section{REFERENCES}

Abram NJ and 8 others (2013) Acceleration of snow melt in an Antarctic Peninsula ice core during the twentieth century. Nature Geosci., 6(4), 404-411 (doi: 10.1038/ngeo1787)

Arthern RJ, Vaughan DG, Rankin AM, Mulvaney R and Thomas ER (2010) In situ measurements of Antarctic snow compaction compared with predictions of models. J. Geophys. Res., 115(F3), F03011 (doi: 10.1029/2009JF001306)

Barrand NE and 6 others (2013) Trends in Antarctic Peninsula surface melting conditions from observations and regional climate modeling. J. Geophys. Res., 118(F1), 315-330 (doi: 10.1029/2012JF002559)

Berthier E, Scambos TA and Shuman CA (2012) Mass loss of Larsen B tributary glaciers (Antarctic Peninsula) unabated since 2002. Geophys. Res. Lett., 39(13), L13501 (doi: 10.1029/ 2012GL051755)

Coléou C, Xu K, Lesaffre B and Brzoska JB (1999) Capillary rise in snow. Hydrol. Process., 13(12-13), 1721-1732

Connolley WM and Bracegirdle TJ (2007) An Antarctic assessment of IPCC AR4 coupled models. Geophys. Res. Lett., 34(22), L22505 (doi: 10.1029/2007GL031648)
Cook AJ and Vaughan DG (2010) Overview of areal changes of the ice shelves on the Antarctic Peninsula over the past 50 years. Cryosphere, 4(1), 77-98 (doi: 10.5194/tc-4-77-2010)

De Angelis $H$ and Skvarca P (2003) Glacier surge after ice shelf collapse. Science, 299(5612), 1560-1562 (doi: 10.1126/ science.1077987)

Dupont TK and Alley RB (2005) Assessment of the importance of ice-shelf buttressing to ice-sheet flow. Geophys. Res. Lett., 32(4), L04503 (doi: 10.1029/2004GL022024)

Ettema J and 6 others (2009) Higher surface mass balance of the Greenland ice sheet revealed by high-resolution climate modelling. Geophys. Res. Lett., 36(12), L12501 (doi: 10.1029/ 2009GL038110)

Fretwell P and 59 others (2013) Bedmap2: improved ice bed, surface and thickness datasets for Antarctica. Cryosphere, 7(1), 375-393 (doi: 10.5194/tc-7-375-2013)

Fyke JG, Carter J and Mackintosh A (2010) Surface melting over ice shelves and ice sheets as assessed from modeled surface air temperatures. J. Climate, 23(7), 1929-1936 (doi: 10.1175/ 2009JCLI3122.1)

Hellmer H, Kauker F, Timmermann R, Determann J and Rae J (2012) Twenty-first-century warming of a large Antarctic iceshelf cavity by a redirected coastal current. Nature, 485(7397), 225-228 (doi: 10.1038/nature11064)

Holland PR and 6 others (2011) The air content of Larsen Ice Shelf. Geophys. Res. Lett., 38(10), L10503 (doi: 10.1029/ 2011GL047245)

Kuipers Munneke P, Van den Broeke MR, Lenaerts JTM, Flanner MG, Gardner AS and Van de Berg WJ (2011a) A new albedo parameterization for use in climate models over the Antarctic ice sheet. J. Geophys. Res., 116(D5), D05114 (doi: 10.1029/ 2010JD015113)

Kuipers Munneke P, Picard G, Van den Broeke MR, Lenaerts JTM and Van Meijgaard E (2011b) Insignificant change in Antarctic snowmelt volume since 1979. Geophys. Res. Lett., 39(1), L01501 (doi: 10.1029/2011GL050207)

Kuipers Munneke P, Van den Broeke MR, King JC, Gray T and Reijmer CH (2012) Near-surface climate and surface energy budget of Larsen C ice shelf, Antarctic Peninsula. Cryosphere, 6(2), 353-363 (doi: 10.5194/tc-6-353-2012)

Lenaerts JTM, Van den Broeke MR, Van de Berg WJ, Van Meijgaard E and Kuipers Munneke P (2012) A new, high-resolution surface mass balance map of Antarctica (1979-2010) based on regional atmospheric climate modeling. Geophys. Res. Lett., 39(4), L04501 (doi: 10.1029/2011GL050713)

Ligtenberg SRM, Helsen MM and Van den Broeke MR (2011) An improved semi-empirical model for the densification of Antarctic firn. Cryosphere, 5(4), 809-819 (doi: 10.5194/tc-5809-2011)

Ligtenberg SRM, Van de Berg WJ, Van den Broeke MR, Rae JGL and Van Meijgaard E (2013) Future surface mass balance of the Antarctic ice sheet and its influence on sea level change, simulated by a regional atmospheric climate model. Climate Dyn., 41(3-4), 867-884 (doi: 10.1007/s00382-0131749-1)

MacAyeal DR and Sergienko OV (2013) The flexural dynamics of melting ice shelves. Ann. Glaciol., 54(63 Pt 1), 1-10 (doi: 10.3189/2013AoG63A256)

Monaghan AJ and 15 others (2006) Insignificant change in Antarctic snowfall since the International Geophysical Year. Science, 313(5788), 827-831 (doi: 10.1126/science.1128243)

Monaghan AJ, Bromwich DH, Chapman W and Comiso JC (2008) Recent variability and trends of Antarctic near-surface temperature. J. Geophys. Res., 113(D4), D04105 (doi: 10.1029/ 2007JD009094)

Morris EM and Vaughan DG (2003) Spatial and temporal variation of surface temperature on the Antarctic peninsula and the limit of viability of ice shelves. In Domack E, Leventer A, Burnett A, Bindschadler RA, Convey $\mathrm{P}$ and Kirby $\mathrm{M}$ eds. Antarctic Peninsula climate variability - historical and paleoenviron- 
mental perspectives. (Antarctic Research Series 79) American Geophysical Union, Washington, DC, 61-68

NCAR Command Language (Version 6.1.3) (2013) UCAR/NCAR/ CISL/VETS, Boulder, CO. http://dx.doi.org/10.5065/D6WD3XH5

Nicholls KW, Makinson K and Venables EJ (2012) Ocean circulation beneath Larsen C Ice Shelf, Antarctica from in situ observations. Geophys. Res. Lett., 39(19), L19608 (doi: 10.1029/ 2012GL053187)

Pritchard HD, Ligtenberg SRM, Fricker HA, Vaughan DG, Van den Broeke MR and Padman L (2012) Antarctic ice-sheet loss driven by basal melting of ice shelves. Nature, 484(7395), 502-505 (doi: 10.1038/nature10968)

Rignot E, Casassa G, Gogineni P, Krabill W, Rivera A and Thomas R (2004) Accelerated ice discharge from the Antarctic Peninsula following the collapse of Larsen B ice shelf. Geophys. Res. Lett., 31(18), L18401 (doi: 10.1029/2004GL020697)

Rott H, Skvarca P and Nagler T (1996) Rapid collapse of northern Larsen Ice Shelf, Antarctica. Science, 271(5250), 788-792 (doi: 10.1126/science.271.5250.788)

Rott H, Müller F, Nagler T and Floricioiu D (2011) The imbalance of glaciers after disintegration of Larsen-B ice shelf, Antarctic Peninsula. Cryosphere, 5(1), 125-134 (doi: 10.5194/tc-5125-2011)

Scambos TA, Hulbe C, Fahnestock M and Bohlander J (2000) The link between climate warming and break-up of ice shelves in the Antarctic Peninsula. J. Glaciol., 46(154), 516-530 (doi: 10.3189/172756500781833043)

Scambos T, Hulbe C and Fahnestock M (2003) Climate-induced ice shelf disintegration in the Antarctic Peninsula. In Domack EW, Burnett A, Leventer A, Conley P, Kirby M and Bindschadler R eds. Antarctic Peninsula climate variability: a historical and paleoenvironmental perspective. (Antarctic Research Series 79) American Geophysical Union, Washington, DC, 79-92

Scambos TA, Bohlander JA, Shuman CA and Skvarca P (2004) Glacier acceleration and thinning after ice shelf collapse in the Larsen B embayment, Antarctica. Geophys. Res. Lett., 31(18), L18402 (doi: 10.1029/2004GL020670)

Scambos T and 7 others (2008) Calving and ice-shelf break-up processes investigated by proxy: Antarctic tabular iceberg evolution during northward drift. J. Glaciol., 54(187), 579-591 (doi: 10.3189/002214308786570836)

Scambos $T$ and 7 others (2009) Ice shelf disintegration by plate bending and hydro-fracture: satellite observations and model results of the 2008 Wilkins ice shelf break-ups. Earth Planet. Sci. Lett., 280(1-4), 51-60 (doi: 10.1016/j.epsl.2008.12.027)

Shepherd A and 46 others (2012) A reconciled estimate of ice-sheet mass balance. Science, 338(6111), 1183-1189 (doi: 10.1126/ science.1228102)

Skvarca P, Rack W and Rott H (1999) 34 year satellite time series to monitor characteristics, extent and dynamics of Larsen B Ice Shelf, Antarctic Peninsula. Ann. Glaciol., 29, 255-260 (doi: 10.3189/172756499781821283)

Trusel LD, Frey KE, Das SB, Kuipers Munneke Pand Van den Broeke MR (2013) Satellite-based estimates of Antarctic surface meltwater fluxes. Geophys. Res. Lett., 40(23), 6148-6153 (doi: 10.1002/2013GL058138)

Van den Broeke MR, Reijmer CH, Van As D, Van de Wal RSW and Oerlemans J (2005) Seasonal cycles of Antarctic surface energy balance from automatic weather stations. Ann. Glaciol., 41, 131-139 (doi: 10.3189/172756405781813168)

Vaughan DG and Doake CSM (1996) Recent atmospheric warming and retreat of ice shelves on the Antarctic Peninsula. Nature, 379(6563), 328-331 (doi: 10.1038/379328a0)

Vaughan DG and 8 others (2003) Recent rapid regional climate warming on the Antarctic Peninsula. Climatic Change, 60(3), 243-274

Wager AC (1972) Flooding of the ice shelf in George VI Sound. Br. Antarct. Surv. Bull., 28, 71-74

Wever N, Fierz C, Mitterer C, Hirashima H and Lehning M (2013) Solving Richards Equation for snow improves snowpack meltwater runoff estimations. Cryos. Discuss., 7(3), 2373-2412 (doi: 10.5194/tcd-7-2373-2013)

Zazulie N, Rusticucci M and Solomon S (2010) Changes in climate at high southern latitudes: a unique daily record at Orcadas spanning 1903-2008. J. Climate, 23(1), 189-196 (doi: 10.1175/ 2009JCLI3074.1)

\section{APPENDIX: CLIMATE DATA 1960-79}

As no R-H3 daily output data are available before 1980, we developed a procedure in which we used a historical, observation-based Antarctic surface temperature and precipitation reconstruction (henceforth referred to as the 'Monaghan reconstruction'; Monaghan and others 2008) to construct a synthetic time series of input fields for the firn model. The Monaghan reconstruction extends back to 1960, allowing us to spin up the model using the baseline period 1960-79. To make the Monaghan data suitable as input to the firn model, two major issues had to be addressed. First, the Monaghan reconstruction is too smooth in a spatial sense $\left(1^{\circ} \times 1^{\circ}\right)$, and not necessarily correct for absolute temperatures. Second, the Monaghan reconstruction only provides monthly mean temperature rather than the required daily values, and it does not provide data on liquid precipitation, evaporation or snowmelt.

The Monaghan reconstruction covers the period 19602011, and overlaps with R-H3 output for the period 198099. For each gridpoint and each month, the R-H3 mean annual cycle of temperature was used to adjust the Monaghan temperatures, both giving them a more appropriate spatial pattern and an improved annual cycle. The magnitude of the adjustment was calculated from the difference between monthly mean $\mathrm{R}-\mathrm{H} 3$ and Monaghan temperatures for the overlapping period. Subsequently, the Monaghan temperatures were corrected for their entire period. Thus, the Monaghan temperature data have an annual mean and cycle that correspond to the R-H3 data, and in that sense are consistent with the R-H3 data. Next, we use an 'analogue method' to obtain daily values for all firn model input parameters for the period 1960-79. The method uses the period 1980-99, for which daily R-H3 data are available, and is illustrated as follows: to obtain daily data for January 1960, we search for the January in the period 1980-99 that has the nearest mean temperature. All the $\mathrm{R}-\mathrm{H} 3$ input data (temperature, precipitation, snowmelt, evaporation) from that nearest January are copied to January 1960. This procedure is repeated for each month for each gridpoint, yielding a dataset that is consistent among the parameters. In other words, the daily climate fields for the period 1960-79 are spliced together from the R-H3 data using the Monaghan monthly mean temperature fields as guidance. The method conserves spatial patterns of natural variability, and accounts for spatially varying relations between temperature and snowmelt. The resulting time series for each gridpoint may exhibit unrealistic stepwise changes at the month boundaries, but this will have a negligible effect on the resulting firn layer.

As a test of its applicability, we applied the analogue method also for the period 1980-99, for which regular R-H3 climate fields are available. The resulting 'analogue product' is compared to the $\mathrm{R}-\mathrm{H} 3$ data for that period, shown in Figure 10 for the Larsen B ice shelf and for January and July. The agreement in surface temperature in Figure 10a and $\mathrm{b}$ is merely a proof that the analogue method has been carried 

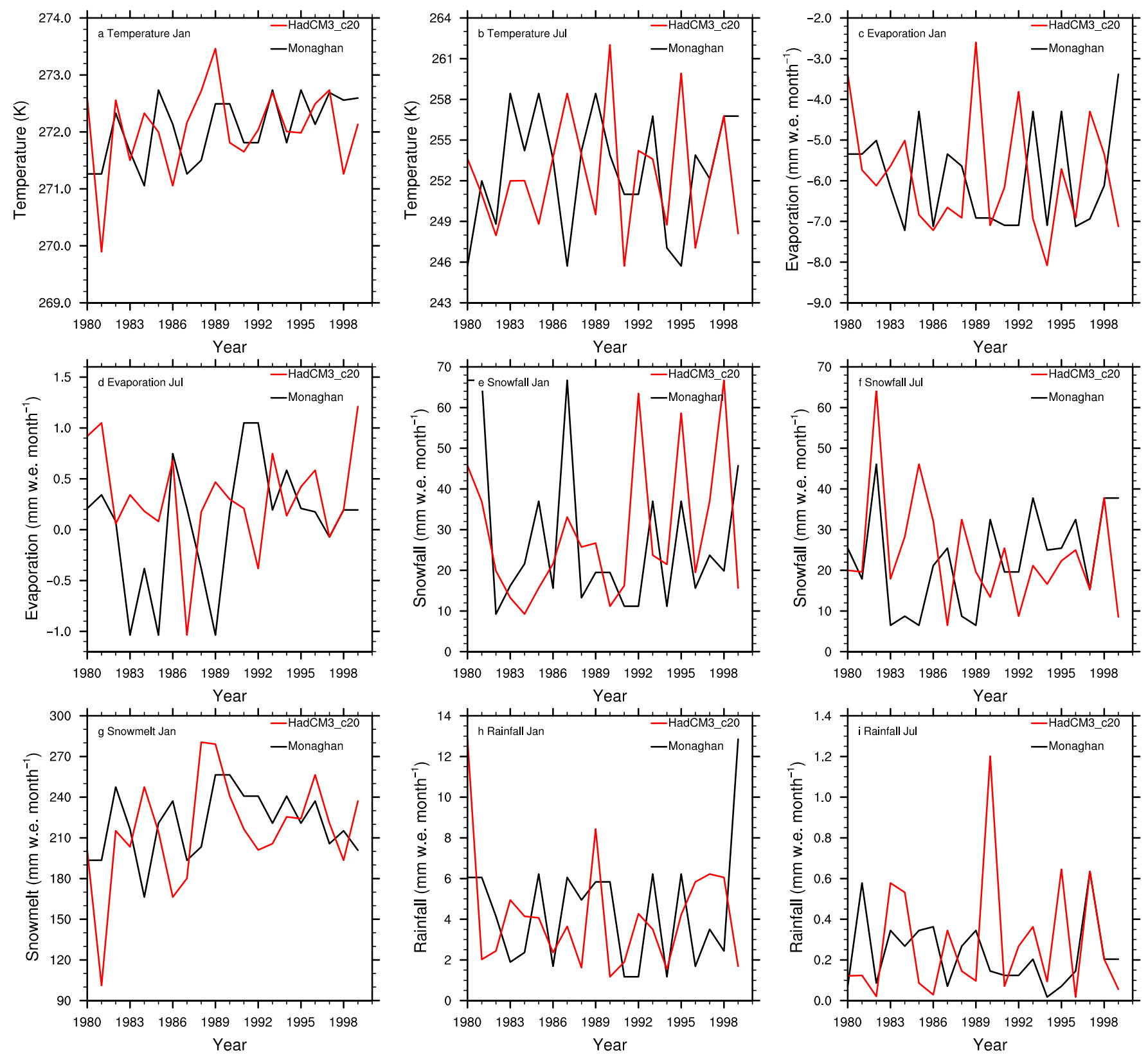

Fig. 10. Test of the analogue method for reconstructing firn model input for 1960-79 using data from an Antarctic surface temperature reconstruction. Curves in red show climate data from the RACMO2 model forced by HadCM3 data for the period 1980-99. Black curves show a reconstruction of these data using the analogue method for the same period. (a) January skin temperature, (b) July skin temperature, (c) January evaporation, (d) July evaporation, (e) January snowfall, (f) July snowfall, (g) January snowmelt, (h) January rainfall and (i) July rainfall. Note that the vertical scales are all different.

out correctly: after all, each mean monthly temperature value in the analogue product is an element of the set of mean monthly values in the $\mathrm{R}-\mathrm{H} 3$ time series. The agreement of the analogue product and $\mathrm{R}-\mathrm{H} 3$ for the other variables, however, shows how well the other climate variables can be transferred from one month to another. This agreement is shown in Figure 10c-i.
Due to the analogue method, the mean snowfall in the period 1960-79 can differ notably from that during 198099. However, it is known that snowfall changes in Antarctica have been insignificant since 1958 (Monaghan and others, 2006). Therefore, we apply a bias correction, that makes the mean snowfall for the period 1960-79 equal to that in the period 1980-99. 